\title{
DEVELOPMENT OF CREATIVE ENTREPRENEURSHIP: OPINION OF MANAGERS FROM ESTONIA, LATVIA, FINLAND AND SWEDEN
}

\author{
Merle Küttim $^{1}$, Katrin Arvola ${ }^{2}$, Urve Venesaar ${ }^{3}$ \\ Tallinn School of Economics and Business Administration, Akadeemia tee 3, 12618 Tallinn, Estonia \\ E-mails: ${ }^{1}$ merle.kuttim@tseba.ttu.ee (correspondingauthor); ${ }^{2}$ katrin.arvola@tseba.ttu.ee; ${ }^{3}$ urve.venesaar@tseba.ttu.ee \\ Received 4 November 2010; accepted 1 July 2011

\begin{abstract}
Due to the nature of the creative sector, which consists of a large number of SMEs and self-employed or part-time employees operating in complex and dynamic environment, the creative enterprises face a number of difficulties and are in need of support. The current study was carried out in the framework of an INTERREG project "Creative Entrepreneurship Training Network - CREAENT". The sample of the study consisted of 74 creative managers from Estonia, Latvia, Finland and Sweden. For data collection structured interviews were carried out. The method of data analysis was thematic content analysis. The creative entrepreneurs found that their weaknesses lay in different entrepreneurial competences. The best ways of acquiring entrepreneurial competences were education and experience, also communication and networking. The aspects that satisfied the creative entrepreneurs about entrepreneurship courses were useful knowledge, suitable teaching methods, new contacts and networks, and creative industry specialised courses. The unsatisfying factors were out-dated and too theoretical knowledge, unsuitable teaching and learning methods and not enough creative industry courses. The future entrepreneurship courses should provide soft skills like communication, negotiation and conflict management; attention should be paid to creative industry specific problems and needs, ways of implementing knowledge in practice, enabling dialogue and peer-teaching among participants.
\end{abstract}

Keywords: entrepreneurship education, creative industries, creative entrepreneurship, entrepreneurial competences.

JEL Classification: A2, L26.

\section{KÜRYBINGO VERSLUMO PLĖTRA: ESTIJOS, LATVIJOS, SUOMIJOS IR ŠVEDIJOS VADOVŲ NUOMONĖ}

\author{
Merle Küttim $^{1}$, Katrin Arvola ${ }^{2}$, Urve Venesaar ${ }^{3}$
}

Talino ekonomikos ir verslo administravimo mokykla, Akadeemia tee 3, 12618 Tallinn, Estija

El.paštas: ${ }^{1}$ merle.kuttim@tseba.ttu.ee; ${ }^{2}$ katrin.arvola@tseba.ttu.ee; ${ }^{3}$ urve.venesaar@tseba.ttu.ee

Iteikta 2010-11-04; priimta 2011-07-01

\begin{abstract}
Santrauka. Kūrybinio sektoriaus, kurio didesnę dalį sudaro smulkiojo ir vidutinio verslo įmonès, savarankiškai dirbantys asmenys ar ne visą darbo dieną dirbantys darbuotojai, veikiantys ịvairiapusiškoje ir dinamiškoje aplinkoje, pobūdis lemia kūrybinių imonių veiklos sunkumus ir kartu paramos poreikị. Šis tyrimas buvo atliktas remiantis INTERREG projektu „Kürybinio verslumo mokymo tinklas - CREAENT“. Tyrimo imti sudarè 74 kūrybiniai vadovai iš Estijos, Latvijos, Suomijos ir Švedijos. Duomenims gauti buvo atliktas struktūrizuotas interviu. Duomenų analizès metodas - teminio turinio analizè. Kūrybinių vadovų interviu duomenimis, jų silpnybės slypi skirtingose verslumo kompetencijose. Geriausi būdai ịgyti verslumo kompetencijų yra ugdymas, patirtis, komunikavimas ir tinklai. Kürybiniams vadovams reikia naudingų žinių, tinkamų mokymo metodų, naujų kontaktų ir tinklų bei specializuotų kūrybinių industrijų kursų. Taigi tokių vadovų nepasitenkinimą lemiantys veiksniai - pasenusios
\end{abstract}


teorinès žinos ir per didelis jų kiekis, netinkami mokymo ir mokymosi metodai, nepakankami kūrybinių industrijų kursai. Ateities verslumo kursai turètų suteikti tokių igūdžių, kaip komunikavimo, derybų ir konfliktų valdymo, dèmesys turètų būti skirtas specifinèms kūrybinių industrijų problemoms ir poreikiams, būdams naudoti igytas žinias praktikoje, sudarantiems sąlygas vykti dialogui ir tarpusavio mokymui tarp dalyvių.

Reikšminiai žodžiai: verslumo ugdymas, kūrybinès industrijos, kūrybingas verslumas, verslumo kompetencijos.

\section{Introduction}

Creative industries constitute an important part of the knowledge economy through the concentration of knowledge, technology, tolerance and finances. It's an important sector of exports and employment, and often also the driver of urban and regional development. The creative and cultural industries exhibit a strong growth in European economy, but this is regionally uneven (in 2001-2006 the Baltic States were one of the areas with higher level of growth, while in Scandinavia only some regions showed higher growth rates) (Power, Nielsen 2010). In order to capitalise on the development of creativity, innovation and economic growth in the creative industries, the state can implement a wide array of support measures, including means that contribute to the development of entrepreneurial competences of creative entrepreneurs.

The creative industries sector is fragmented in that it comprises a large number of small enterprises and a small number of large enterprises. Therefore the characteristics of small enterprises apply to the creative sector. Many people working within the creative industries are self-employed and/or work part-time sometimes in addition to full time salaried occupations and many are driven by quality of life imperatives. Therefore their dedication to business management is low and they often lack time for business processes. There is also a strong sense that the creative industries are very much rooted at the local level, that they have a sense of place and that localities are important in fostering enterprise and synergies and in facilitating mutually supportive partnerships and networks (Jones et al. 2004: 134).

For the reasons mentioned above, it becomes obvious that different ways of intervention are needed in order to support the development of the creative industries. Jo Foord (2008) has divided practical interventions of creative fields into six broad categories: 1 . Property and premises strategies. 2. Business development, advice and network building. 3. Direct grants and loans schemes to creative business/ entrepreneurs. 4. Fiscal initiatives. 5. Physical and IT infrastructure. 6. Soft infrastructure.

These categories are not exclusive, but they provide a profile of the main types of intervention and therefore the mechanisms used to promote and support creative enterprise in particular localities. Foord's study showed that the soft interventions of advice, skills and enterprise training for start-ups and entry level employment are dominating. Higher level interventions in technology infrastructure, international marketing and IP legal frameworks were rare (Foord 2008). In the current study, the second category of intervention "Business Development, Advice and Network Building" in terms of entrepreneurship education is investigated.

We can ask whether enterprise can be taught and is it needed. Studies have shown that there exists a link between entrepreneurship training programs and the perceptions of the desirability and feasibility of starting a business (Levie et al. 2009b: 5; Peterman, Kennedy 2003), the intentionality of engaging as an entrepreneur (Pittaway, Cope 2007: 498; Volery, Mueller 2006: 13-14; Degeorge, Fayolle 2008: 23) and the business start-up activity (Levie et al. 2009a: 9; Henry et al. 2004: 265; Clercq, Arenius 2006: 350-351).

Enterprise education for creative industries is gaining momentum as a means of supporting the development of innovation, creativity and economic growth. Carey and Naudin (2006: 526) found that the role of the university is to insert the entrepreneurial spirit among students from creative fields through embedding attitudes and including entrepreneurial activities in project-based work, integration into the local creative sector, exposure to practitioners and attendance at seminars. As to the need, due to the nature of the creative sector which is so reliant on freelancers, small business ownership and a steady flow of new talent - it was considered essential for creative graduates to be leaving university with a clearer idea of working within this industry.

According to competence theory such components of entrepreneurial competences as knowledge and experience, motivation, capabilities, characteristics enable a person to undertake and succeed in entrepreneurship. Knowledge and experience include understanding about market, environment, people, production and finances. Motivation could be internally driven (autonomy, achievement, power) or externally driven (unemployment, gap in the market, interest in subject, certainty of clients). Capabilities depend on company's life cycle, concentrating more on market orientation, creativity and flexibility during the early phase and on managing, motivating, organising/planning, financially administrating during the mature phase. Characteristics can include such traits as achievement, autonomy, power, affiliation, effectiveness, endurance, taking risks and thinking styles (Driessen, Zwart 2007: 2-5). An entrepreneurial competency consists of a combination of skills, knowledge and resources that entrepreneurs largely acquire on an 
individual basis. For student-entrepreneurs to master a competency in the classroom, they must be fully engaged in activities that will teach it to them (Fiet 2000: 107).

The general interest of university students and young graduates of creative fields from Central Baltic Region in entrepreneurship is low and enterprises founded have often no relation to the owner's academic expertise. One of the reasons is that the graduates from creative universities/polytechnics have not enough business competences for developing internationally competitive new ventures (Creative... 2009). Awareness should be established within the creative sector that these industrial players operate in an economic playing field that necessitates business knowledge and they need to acquire business smarts and interact, learn and benefit from other industrial areas (Nilsson, Etelä 2006).

Therefore, there are a number of issues to overcome in institutional and course development level in order to successfully combine business and creative disciplines. On institutional level the universities and other educational institutions should take into account that cultural entrepreneurs are interested in modular, flexible and demand-led education, in distance form and taught by peers (Leadbeater, Oakley 1999: 42-43). Another issue on the institutional level is the difficulty of advancing inter-disciplinary teaching and learning as institutional realities do not favour it (Wilson 2009: 185-186). There is also a need for closer relationships with external organisations, industry and practitioners (Carey, Naudin 2006: 522-525).

On course development level enterprise education in creative industries should be embedded into every-day teaching process, it should involve competent staff and relevant textbooks (Ibid, 522-525) as the skills needed by creative entrepreneurs are wider than the term 'entrepreneurship' generally contains and include a range of "soft" skills such as communication, team-working, customer handling, presentation, project management, etc., (Developing... 2006: 21). Also the nature of entrepreneurial learning needs to be incorporated into teaching and learning taking into account such components as the connectedness of the individual with their social context, including personal and social emergence, contextual learning and the negotiated enterprise (Rae 2004: 494-500).

The objective of the article is to analyse the state and problems of entrepreneurial competences and entrepreneurship education of creative sector managers and the ways of developing them in four Baltic Sea Region countries Estonia, Latvia, Finland and Sweden.

The structure of the remaining article includes overview of research methods, research results in the areas of most important entrepreneurial competences, gaps in competences, ways of obtaining entrepreneurial competences and evaluation of entrepreneurship education in creative industries, discussion and conclusion about the study results, limitations and future areas of research.

\section{Methods}

The study was carried out in the framework of an INTERREG program project "Creative Entrepreneurship Training Network - CREAENT". The main objective of the project was linking knowledge and innovation to sustainable economic development and competitiveness of the programme area and development of a best practice model of entrepreneurial education for creative industry in Central Baltic Region universities. This would allow them to better promote entrepreneurial thinking among young people, and support innovative business start-ups from creative industry and their development into growth companies, better cross-border interaction in innovation and creative cluster development and joint marketing (Creative... 2009).

The classification of a creative industry for the purpose of this study was put together uniting the Finnish and Estonian government classifications of the creative industry to include the following sectors: architecture, visual/fine arts, performing activities, audio-visual activities, design, entertainment IT, cultural heritage, music production and event services, advertisement and marketing communication and interdisciplinary sector. The sample of the study consisted of 74 creative entrepreneurs from 4 countries divided as follows: 21 from Estonia, 25 from Latvia, 21 from Finland and 7 from Sweden. The criteria for selection of respondents were that they represented as different areas of creative industries as possible (e.g. architecture, design, entertainment IT, visual/ fine arts, music production, advertising, etc.). Interviews took place in the form of face-to-face contacts, the answers were recorded and later transcribed and then interview summaries were translated into English in order for the data gathered in different countries to be available for analysis.

The study was conducted according to the principles of analytic induction during which the researchers sought to find universal explanations of phenomena by pursuing the collection of data until no cases that are inconsistent with a hypothetical explanation of phenomena were found (Bryman 2004: 400).

For data collection structured interviews with creative entrepreneurs in 4 countries were carried out based on a previously developed interview guide. During the interviews information was gathered about the background of the interviewee and the enterprise, the motivation of becoming an entrepreneur and future plans, the problems and support received during the start-up phase, the state, plans and problems related to the internationalisation of business activities, relevant entrepreneurial knowledge-skills, strengths and weaknesses, participation in entrepreneurship courses and its assessment, and how entrepreneurship education for creative industries should be developed.

The method of data analysis was thematic content analysis (Anderson 2007) of the interview data based on categories derived from the literature review. The categories of 
entrepreneurial competences that were used were: knowledge and experience, motivation, personal characteristics and capabilities.

\section{Results}

\subsection{Most important entrepreneurial competences}

The competences that were considered the most essential by creative sector managers were manifold like entrepreneurial knowledge, experiences, personal characteristics, personal capabilities, and motivation.

The areas of knowledge considered most important were understanding the business environment and principles of entrepreneurship, issues of business law, financial management and accounting, IT, marketing, selling and advertising, management like strategic thinking, leadership and planning, inter-personal communication like knowing how to make contacts with people, understanding people and self-presentation skills (Table 1). In addition to knowledge, practical implementation of it was important as the only way how to understand the business world was when you have actually worked in it.

The most important conclusion was that a creative entrepreneur should understand a little of everything - be a generalist - in order to run a successful business. In addition to learnable knowledge and skills, some things are acquired only through practice, some depend on personality traits.

There were a number of personal characteristics that entrepreneurs considered essential like striving for achievement, autonomy, and power, the need to belong somewhe- re, being effective and enduring hardships and unexpected turns of events, being able to take risks and finally, being ethical in business conducts (Table 2).

Capabilities or what one was able to do, were also vital like orientation towards the market and understanding how it functioned, creativity in order to find new solutions, flexibility to be able to adapt, ability to manage the enterprise and lead others, motivation to believe in oneself and stay disciplined, ability to organise and plan activities and time, ability to balance the budget and ability to cooperate with clients, co-workers, partners.

Motivation varied for respondents - being either external or internal. External was the desire to achieve a certain status and power through managing a company, internal was interest in engaging in entrepreneurship in the field of creative industry.

\subsection{Gaps in entrepreneurial competences}

The main weakness for creative managers was that they didn't feel like traditional businessmen - "making a lot of money fast" wasn't the main goal.

Lack of knowledge in different areas was seen as a major gap in entrepreneurial competences, e.g. not knowing the business environment, not having the financing and accounting skills, being weak in selling, also in management and inter-personal relations, having weak knowledge of the sector, entrepreneurship and poor language skills (Table 3).

Lack of experience was a problem in the sense of experience with entrepreneurship and previous work-experience in the field.

Table 1. Entrepreneurial competences related to knowledge and experiences ${ }^{1}$

\begin{tabular}{l|l}
\hline Knowledge & \\
\hline Environment & $\begin{array}{l}\text { Practical knowledge on business law, copyright, labour laws (EE_Ent04); Information technology, social } \\
\text { media know-how (FI_Ent08); Politics, economics, culture and many others (EE_Ent09). }\end{array}$ \\
\hline Finances & $\begin{array}{l}\text { Accounting and business skills, so that the money should also have been idle and not just rely on } \\
\text { subsidies (FI_Ent03). }\end{array}$ \\
\hline Market & Marketing and selling skills are also very important (EE_Ent02); Advertising skill (EE_Ent11). \\
\hline Management & Leadership, team work skills and also business management skills (LV_Ent05). \\
\hline People & Communication skills and understanding people (EE_Ent03); The ability to create networks (FI_Ent01). \\
\hline Production & $\begin{array}{l}\text { A good entrepreneur needs to know not only his duties, but also all the things in detail that are } \\
\text { happening in the lower levels of the company, including the technical issues (LV_Ent12). }\end{array}$ \\
\hline Entrepreneurship & Business understanding (FI_Ent14). \\
\hline Experiences & \multicolumn{2}{l}{$\begin{array}{l}\text { I think experience is the most important skill. A creative person does not understand the business world } \\
\text { experiences }\end{array}$} & \begin{tabular}{l} 
Previous experiences (EE_Ent14). \\
\hline Life experiences
\end{tabular} \\
\hline
\end{tabular}

1 Here and in the following Tables interviews are named to include country abbreviation (EE, LV, FI, SE), reference to enterprise (Ent) and number, e.g. FI_Ent17. 
Table 2. Entrepreneurial competences related to characteristics, capabilities and motivation

\begin{tabular}{|c|c|}
\hline Characteristics & \\
\hline Achievement & Belief in yourself, ambitiousness (FI_Ent17); Enthusiasm (LV_Ent10). \\
\hline Autonomy & Independence (FI_Ent11). \\
\hline Power & Be a good leader (LV_Ent13). \\
\hline Affiliation & Loyalty (LV_Ent03). \\
\hline Effectiveness & Flexibility, precision (LV_Ent10); Versatility (LV_Ent01); Discipline (EE_Ent05). \\
\hline Endurance & Tolerate uncertainty (FI_Ent04); Perseverance (FI_Ent12). \\
\hline Taking risks & Courage (EE_Ent03); Entrepreneurial spirit (FI_Ent11). \\
\hline Ethics & $\begin{array}{l}\text { Openness, decency, unselfishness (LV_Ent01); Responsibility (EE_Ent03); } \\
\text { Honesty (LV_Ent04). }\end{array}$ \\
\hline \multicolumn{2}{|l|}{ Capabilities } \\
\hline Market orientation & The ability to see the trends in the society, the ability to predict these trends (LV_Ent09). \\
\hline Creativity & $\begin{array}{l}\text { Maybe being able to see things from the other side, to see outside the box and to see new solutions } \\
\text { (SE_Ent03); Ability to see the opportunity of the changing situations (FI_Ent12). }\end{array}$ \\
\hline Flexibility & An ability to adapt to the changing situation (FI_Ent12). \\
\hline Manage & Ability to attract and establish a team of people who share similar values (LV_Ent03). \\
\hline Motivate & $\begin{array}{l}\text { You have to be brave and believe in what you are doing. You need to have discipline, because nobody is } \\
\text { telling me when to be at work, nobody is getting angry at me (SE_Ent07). }\end{array}$ \\
\hline Organise, plan & $\begin{array}{l}\text { You have to be able to finish things, you have to set your own dead-lines, and you have to lead yourself } \\
\text { (SE_Ent04). }\end{array}$ \\
\hline $\begin{array}{l}\text { Financial } \\
\text { administration }\end{array}$ & Keeping the budget, be realistic, the ability to see the product potential (FI_Ent07). \\
\hline Co-operation & $\begin{array}{l}\text { Co-operation ability (EE_Ent03); Needs to have good communication skills, has to be able to negotiate } \\
\text { (LV_Ent22). }\end{array}$ \\
\hline \multicolumn{2}{|l|}{ Motivation } \\
\hline $\begin{array}{l}\text { Achievement, } \\
\text { power }\end{array}$ & $\begin{array}{l}\text { The desire and eagerness to manage the company. Thus, the most important thing is an attitude } \\
\text { (FI_Ent02). }\end{array}$ \\
\hline Interest in subject & The understanding that the creative industries are a real business - motivation (LV_Ent07). \\
\hline
\end{tabular}

Table 3. Gaps in competences related to knowledge and experiences

\begin{tabular}{l|l}
\hline Knowledge & \\
\hline Environment & $\begin{array}{l}\text { Legislation (EE_Ent20); Weaknesses of predicting the growth of population in the municipalities, } \\
\text { which would be important to be able to anticipate the premises of local needs (FI_Ent12). }\end{array}$ \\
\hline Finances & $\begin{array}{l}\text { Skills and knowledge of how to find financing (EE_Ent17); Missing knowledge about basic things } \\
\text { like accounting (EE_Ent19); Weak in looking for sponsors (LV_Ent18). }\end{array}$ \\
\hline Market & $\begin{array}{l}\text { I'm not so good at selling myself, I could definitely be better (SE_Ent07); Marketing and selling. It } \\
\text { is very difficult to sell something that you have created yourself (EE_Ent05); Customer attraction } \\
\text { skills (LV_Ent02). }\end{array}$ \\
\hline Management & $\begin{array}{l}\text { Lack of time due to bad time management (EE_Ent06); Lack of strategic thinking and planning } \\
\text { (LV_Ent01). }\end{array}$ \\
\hline People & $\begin{array}{l}\text { Keeping relationships at any price (EE_Ent12); Persuasion skills and ability to clearly communicate } \\
\text { the vision and standpoint to clients (LV_Ent05); Giving promises (LV_Ent01). }\end{array}$ \\
\hline Knowledge of sector & $\begin{array}{l}\text { The knowledge of the art sector could be better (FI_Ent01); Lack of knowledge about music } \\
\text { industry (LV_Ent17). }\end{array}$ \\
\hline Entrepreneurship & $\begin{array}{l}\text { Missing knowledge about entrepreneurship (EE_Ent18); V. does not have a business education, } \\
\text { which she finds lack of knowledge (FI_Ent02). }\end{array}$ \\
\hline Language skills & $\begin{array}{l}\text { Poor language skills (EE_Ent12); } \\
\text { The English language skills also could be improved (LV_Ent05). }\end{array}$ \\
\hline Experiences & \\
\hline Professional \\
experiences
\end{tabular}


Also, certain personal traits hindered business activities like being too modest and not ambitious, not independent enough, not interested in money and power, not being sure were one belongs, being too gentle and undetermined, not liking taking risks, being too honest or not tolerant enough (Table 4).

Lack of certain capabilities was seen as a weakness like lack of market orientation, being too creative and flexible, not seeing managerial mistakes, being not enough selfmotivated, being weak in time-planning and organisation and financial matters.
Lack of motivation in terms of need for achievement and power or interest in developing the company was seen as a problem.

The respondents found weaknesses in all the areas of the most important entrepreneurial competences. Working with numbers, accounting and financial planning was especially difficult for creative people, also time-management and planning, deciding whether to prefer artistic aims over financial ones (doing what one likes or what earns income).

Table 4. Weaknesses related to characteristics, capabilities and motivation

\begin{tabular}{|c|c|}
\hline Characteristics & \\
\hline Achievement & Modesty (EE_Ent13); The reluctance to do uncomfortable tasks (LV_Ent06). \\
\hline Autonomy & I doubt myself too much (SE_Ent01); Insecurity (LV_Ent09). \\
\hline Power & I don't know how to be a classical business man and how to make money (EE_Ent01). \\
\hline Affiliation & I have problems to believe where I belong - it's between design, art, and crafts (SE_Ent06). \\
\hline Effectiveness & $\begin{array}{l}\text { I am too flexible, and do not stick to our position in situations when I should (LV_Ent21); } \\
\text { Sometimes I am too gentle when I should be stricter (EE_Ent08); } \\
\text { One more weakness is lack of punctuality (LV_Ent19). }\end{array}$ \\
\hline Endurance & $\begin{array}{l}\text { A resistance to stress could be better (FI_Ent03); Greater persistence I could have (FI_Ent14); } \\
\text { Unpredictability, impatience (LV_Ent08). }\end{array}$ \\
\hline Taking risks & $\begin{array}{l}\text { We don't like taking risks, sometimes we waste too much time on things that earn us very little } \\
\text { money (EE_Ent07); } \\
\text { O. does not have the courage to do big projects with borrowed money. She is afraid of taking risks } \\
\text { (FI_Ent06). }\end{array}$ \\
\hline Ethics & $\begin{array}{l}\text { Too much honesty in our activities (LV_Ent04); The respondent can be not tolerant enough at } \\
\text { times when, for example, a client does not understand or agree with the concepts or ideas offered } \\
\text { (LV_Ent11). }\end{array}$ \\
\hline \multicolumn{2}{|l|}{ Capabilities } \\
\hline Market orientation & Unwillingness to do what is the most selling thing to do, but that is also strength (SE_Ent05). \\
\hline Creativity & $\begin{array}{l}\text { E. is sometimes too innovative. Sometimes she needs to concentrate on the projects better } \\
\text { (FI_Ent09). }\end{array}$ \\
\hline Flexibility & We would also need more structure in our everyday processes. Self discipline (EE_Ent10). \\
\hline Manage & $\begin{array}{l}\text { Weakness for the whole company is the very divisional tasks, such that one cannot help or } \\
\text { substitute with another (LV_Ent14). }\end{array}$ \\
\hline Motivate & $\begin{array}{l}\text { Weakness of the respondent is laziness to some extent, because, as there are almost no deadlines } \\
\text { and day-to-day tasks set, one needs to self-motivate a lot (LV_Ent14). }\end{array}$ \\
\hline Organise, plan & $\begin{array}{l}\text { I am also very bad at time planning and I can't separate important things from unimportant } \\
\text { (EE_Ent01). }\end{array}$ \\
\hline $\begin{array}{l}\text { Financial } \\
\text { administration }\end{array}$ & $\begin{array}{l}\text { You are standing in the art and in the business and you are afraid that you'll fall over to the } \\
\text { business side. But you need the business side to make the living (SE_Ent03); } \\
\text { Working with numbers (EE_Ent03). }\end{array}$ \\
\hline \multicolumn{2}{|l|}{ Motivation } \\
\hline Achievement & $\begin{array}{l}\text { I am too comfortable and should have more ambitions (EE_Ent03); Sometimes I have lack of } \\
\text { motivation to work for so many hours a day (LV_Ent24). }\end{array}$ \\
\hline Power & $\begin{array}{l}\text { Lack of goal oriented operation and the desire to earn high profits. We are not traditional business } \\
\text { people (EE_Ent } 04 \text { ). }\end{array}$ \\
\hline Interest in subject & $\begin{array}{l}\text { The respondent only cares about filling the lower levels of Maslow's pyramid in order to freely } \\
\text { work as a director, instead of trying to develop the enterprise as such (LV_Ent15). }\end{array}$ \\
\hline
\end{tabular}




\subsection{The best ways of obtaining entrepreneurial competences/overcoming weaknesses}

The best way of obtaining entrepreneurial competences was thought to be by creative managers either education or experience or a combination of the former (Table 5). The preferred variant was education and practice or learning solely through experience, academic education on its own was considered unsuitable to prepare for such a practical activity as entrepreneurship.

Sharing experiences and communication contributed also to entrepreneurial competences. It helped to be involved in different networks, hearing about other people's experiences, getting knowledge from experienced entrepreneurs. But there were also opinions that entrepreneurial competences depend solely on background or entrepreneur's personality and cannot be learned.

One of the best ways of obtaining entrepreneurial skills was thought to be a combination of learning and life and professional experiences as the two complement each other.
Experience itself was also important as it was beneficial to have some kind of experience before starting an enterprise, like working before as a self-employed person or being employed by someone else.

\subsection{Evaluation of entrepreneurship courses}

The evaluations of entrepreneurship courses that the creative sector managers had participated in were quite contradictory. Those who were satisfied were contented with such aspects as the usefulness of courses in terms of acquired knowledge, suitable teaching and learning methods, increased entrepreneurial motivation, networking opportunity, focus on creative industries and subsidies for participation (Table 6).

The courses provided useful knowledge like how to prepare a business plan, understanding core business, management. The courses also utilised suitable teaching and learning methods like open dialogue, group and individual couching, providing feed-back, preparing and distributing

Table 5. Ways of obtaining entrepreneurial competences

\begin{tabular}{l|l}
\hline Education & $\begin{array}{l}\text { Education and training can enhance skills, but the attitude can be difficult to teach (FI_Ent02); } \\
\text { It is impossible to acquire them only with education, the best model is to have both - talent and } \\
\text { education, for me the education is as an additional force that helps to develop ideas (LV_Ent21). }\end{array}$ \\
\hline $\begin{array}{l}\text { Education and } \\
\text { experience }\end{array}$ & $\begin{array}{l}\text { These skills are all learnable to some stage. Experience is always important. I think people should } \\
\text { have a little experience before they start to learn something (EE_Ent08); } \\
\text { Studying in different programs, learning-by-doing, getting knowledge from experienced } \\
\text { entrepreneurs (EE_Ent14). }\end{array}$ \\
\hline Experience & $\begin{array}{l}\text { As the respondent has learned everything he needs in a practical approach, he believes that it is the } \\
\text { most appropriate way, because the academic skills need to be re-learned and somewhat re-invented } \\
\text { once applied in practice (LV_Ent14). }\end{array}$ \\
\hline $\begin{array}{l}\text { Communication and } \\
\text { networking }\end{array}$ & $\begin{array}{l}\text { It is good to hear about other people's experiences (EE_Ent06); It is good to get involved in } \\
\text { different networks (EE_Ent02). }\end{array}$ \\
\hline $\begin{array}{l}\text { Social background and } \\
\text { personality }\end{array}$ & $\begin{array}{l}\text { No one universal way, a combination of family upbringing and experience (LV_Ent01); } \\
\text { Most of the skills depend on the personality of the entrepreneur (LV_Ent13). }\end{array}$ \\
\hline
\end{tabular}

Table 6. Satisfying factors of entrepreneurship courses

\begin{tabular}{l|l}
\hline $\begin{array}{l}\text { Provided useful } \\
\text { knowledge }\end{array}$ & $\begin{array}{l}\text { I would have never been able to prepare a business plan on my own (EE_Ent06); Management } \\
\text { courses were very useful. They helped me in running a company (LV_Ent16). }\end{array}$ \\
\hline $\begin{array}{l}\text { Suitable teaching and } \\
\text { learning methods }\end{array}$ & $\begin{array}{l}\text { There we had an opportunity to ask all kinds of questions and we had to give presentations on each } \\
\text { stage of the business plan. It was also very useful to get feedback from other people (EE_Ent06). }\end{array}$ \\
\hline $\begin{array}{l}\text { Increased motivation } \\
\text { The course created faith in doing own business (FI_Ent08); However, the courses told her to believe } \\
\text { in herself (FI_Ent17). }\end{array}$ \\
\hline $\begin{array}{l}\text { Provided contacts, } \\
\text { networking } \\
\text { opportunity }\end{array}$ & Possibilities to develop the network were obtained (EE_Ent13). \\
\hline $\begin{array}{l}\text { Enough creative } \\
\text { industry specialised } \\
\text { courses }\end{array}$ & There are more creative industry specialised courses available as well now (EE_Ent05). \\
\hline $\begin{array}{l}\text { Subsidies available in } \\
\text { order to participate }\end{array}$ & And I am especially grateful because I've had subsidies to take these courses (EE_Ent03). \\
\hline
\end{tabular}


handouts. The trainings were said to have raised motivation in terms of readiness to start with entrepreneurship as they increased confidence and belief in succeeding. The courses provided also contacts and a networking opportunity, which was considered important. There were enough creative industry specialised courses which took into account the specific context of the field. And subsidies were provided to participants, which made the courses more readily available.

The interviewees who were unsatisfied mentioned such aspects as out-dated and too theoretical knowledge, unsuitable teaching and learning methods, unsuitable organisation of the courses, and not enough focus on creative industries (Table 7).

Out-dated, unnecessary knowledge provided during trainings created dissatisfaction because of the poor quality of courses that didn't correspond with learners' needs. Too theoretical and formal courses were also valued low as they lacked practical real-life connections with examples how to implement it in every-day life, which would have been connected to the entrepreneurs' real problems and ways of solving them.

Teacher's personality and way of teaching were unsatisfactory as sometimes the attitude was unprofessional or uninspiring. Also dialogic and more individualised methods were needed. The organisation of courses was considered to be unsuitable as they were sometimes too long, not in a right place during the studies - either too early or too late.

Dissatisfaction means also that the courses should be more focused on creative industries, but not too technological or artistic, focusing also on soft skills like cooperation and communication.

The reasons for both satisfaction and dissatisfaction can be summarised as practical learning, meaning various things like connectedness of theory with practice, providing real-life examples, professionals as lecturers, organising field-practice, sharing experiences and best-practice, providing solutions to real problems in the creative sector.

\section{Discussion and conclusions}

The creative sector managers need business competences to be competitive in the dynamic and complex environment, but since these knowledge and skills are acquired more through experience and peer-to-peer communication, the role and content of entrepreneurship education needs to be seriously reviewed and adjusted to suit the expectations and needs of learners. The current study is one of the first attempts to interview creative entrepreneurs and obtain first-hand information about their entrepreneurship education problems and needs.

In terms of entrepreneurial competences the creative entrepreneurs find that that the most important competences lay in entrepreneurial knowledge and experience, capabilities, characteristics and motivation. Management and inter-personal communication skills are especially vital as the field requires networking and co-operation with staff, other firms in the same field, providers, resellers, clients, etc. The need for communication and networking skills is explained by the nature of creative industries that can be seen as a set of agents in a market characterized by adoption of novel ideas within social networks for production and consumption (Potts et al. 2008: 170-177).

At the same time entrepreneurs conclude that they have weaknesses in all these areas. The main problem seems to be the difficulty to balance artistic and business objectives, manage and plan effectively. There is also the issue of motivation as especially in the start-up phase the work requires extra hours and the pay is low, there is also the need for selfdiscipline, setting own deadlines, being strict, which requires the ability to self-motivate oneself and inspire others.

Table 7. Unsatisfying factors of entrepreneurship courses

\begin{tabular}{l|l}
\hline $\begin{array}{l}\text { Provided useless } \\
\text { knowledge }\end{array}$ & $\begin{array}{l}\text { The program was too outdated, but the respondent was looking for a way to hear about the newest } \\
\text { tendencies and technologies (LV_Ent13). There is too much theoretical knowledge provided that is } \\
\text { not applicable in real life, because nobody has shown how. Much more practical learning should be } \\
\text { provided (LV_Ent14). }\end{array}$ \\
\hline $\begin{array}{l}\text { Unsuitable teaching } \\
\text { and learning methods }\end{array}$ & $\begin{array}{l}\text { The approach and attitude was too unprofessional, too school-like. More practical, mentor-like } \\
\text { attitude was needed (LV_Ent13). }\end{array}$ \\
\hline $\begin{array}{l}\text { Unsuitable } \\
\text { organisation of courses }\end{array}$ & $\begin{array}{l}\text { Creative entrepreneurship courses are sometimes too long and some topics are especially stretched } \\
\text { (EE_Ent02); The course should be earlier in your education, not the last thing, because you could } \\
\text { use it in your education, to start thinking about your business earlier, like a motor for you business } \\
\text { (SE_Ent04). }\end{array}$ \\
\hline $\begin{array}{l}\text { Not enough creative } \\
\text { industry specialised } \\
\text { courses }\end{array}$ & $\begin{array}{l}\text { There are a lot of courses available but they should be more specifically to creative industry (EE_- } \\
\text { Ent10); Architecture does not involve classical entrepreneurship because the entrepreneurship in } \\
\text { architecture is rather conditional and limited compared to, for example, production of goods, an } \\
\text { architectural entrepreneurship involves cooperation and communication with a client (LV_Ent05). }\end{array}$
\end{tabular}


The best ways of acquiring entrepreneurial competences and overcoming weaknesses were thought to be education and experience, especially the combination of the two, also communication and networking, learning from experiences of other entrepreneurs and from each other during a course. Experience was valued even more than education since practical knowledge of the field, basic first-hand understanding of business, contacts and prospective marketing channels were considered necessary before starting a business.

The evaluations of entrepreneurship courses were contradicting. The aspects that satisfied the creative entrepreneurs were useful knowledge, suitable teaching and learning methods, increase of motivation, new contacts and networks, subsidies for participation and finally enough creative industry specialised courses. The unsatisfying factors were out-dated and too theoretical knowledge, unsuitable teaching and learning methods, unsuitable organisation of courses and not enough creative industry courses. It's therefore important to get practical support, help in solving real issues, knowledge how to apply theory in practice, obtain an idea what the business world is like and how to manage in it; there should be more mentoring than class-room teaching, but also group-work, practical learning from business to business, professionals as lecturers, practical experience. Another aspect is teaching methods as sometimes how dominates over what, and students expect high professional competency, a unique type of communication, multi-faceted learning methods and interactivity (Hägg 2008: 23).

As to differences between countries, since the market economy is much younger in Estonia and Latvia than in Finland and Sweden there were problems with finding qualified lecturers with up-to-date teaching materials. Inviting guest lecturers was problematic from the aspect of knowing the country specific context and whether the knowledgeskills or examples can be transferred and implemented in the business environment of another country. Also, due to the smaller market in Estonia and Latvia it was more difficult to find suitable personnel and the problem for managers was creating a team with qualified specialists. The same applied to the possibilities of selling services/products, which were more limited in smaller markets.

The future entrepreneurship courses should provide soft skills like communication, negotiation and conflict management in addition to more traditional entrepreneurship topics like financing and accounting, marketing and selling. Attention should be paid also to creative industry specific problems and needs, ways of implementing knowledge in practice for solving real problems, involving practitioners as examples of best-practice and enabling dialogue and peerteaching among participants.

The limitations of the current study were connected with the fact that although an attempt was made to include different creative enterprises in the sample, not all areas of creative industries have been covered. The original idea was to include in the sample only start-ups, but in some countries also managers of more mature enterprises have been interviewed.

Further research should therefore concentrate on a deeper analysis of differences between countries, enterprises in various stages of development and different fields of creative industries. A question should be posed for example whether the entrepreneurship education needs of architects and artists and sculptors are different and in what respect, also whether differences exist for enterprises that are 1 or 10 years old. The future activities of the CREAENT project, that the current article is a part of, include also the objective of developing an entrepreneurship education module for creative industries based on the study of the opinions and experiences of creative sector managers.

\section{References}

Anderson, R. 2007. Thematic Content Analysis (TCA): Descriptive Presentation of Qualitative Data [online], [cited 05 November 2010]. Available from Internet: <http:// www.wellknowingconsulting.org/publications/pdfs/ ThematicContentAnalysis.pdf $>$.

Bryman, A. 2004. Social Research Methods. Second edition. New York: Oxford University Press.

Carey, C.; Naudin, A. 2006. Enterprise curriculum for creative industries students. An exploration of current attitudes and issues, Education and Training 48(7): 518-531. doi:10.1108/00400910610705908

Clercq, De D.; Arenius, P. 2006. The role of knowledge in business start-up activity, International Small Business Journal 24(4): 339-358. doi:10.1177/0266242606065507

Creative Entrepreneurship Training Network, CREAENT. 2009. Application form Central Baltic Interreg IV A Programme 2007-2013.

Degeorge, J. M.; Fayolle, A. 2008. Is entrepreneurial intention stable through time? First insights from a sample of French students, International Journal of Entrepreneurship and Small Business 5(1): 7-27. doi:10.1504/IJESB.2008.015951

Developing Entrepreneurship for the Creative Industries: the Role of Higher and Further Education. 2006. Department for Culture, Media and Sport, Creative Industries Entrepreneurship Task Group [online], [cited 05 November 2010]. Available from Internet: <http://www.seco.org.uk/elibrary/ creativeindustries/developingentrepreneurshipforthecreativ eindustriestheroleofhigherandfurthereducation.html>.

Driessen, M. P.; Zwart, P. S. 2007. The Entrepreneur Scan Measuring Characteristics and Traits of Entrepreneurs [online]. Available from Internet: <http://www.necarbo.eu/files/Escan $\% 20 \mathrm{MAB} \% 20$ Article.pdf $>$.

Fiet, J. O. 2000. The pedagogical side of entrepreneurship theory, Journal of Business Venturing 16: 101-117. doi:10.1016/S0883-9026(99)00042-7

Foord, J. 2008. Strategies for creative industries: an international review, Creative Industries Journal 1(2): 91-113. doi:10.1386/cij.1.2.91_1 
Hägg, O. 2008. Entrepreneurial identity transition during an entrepreneurial training program in creative industries, in Conference Presentation, European Summer University Conference in Entrepreneurship 2008 by Bodø Graduate School of Business and Nordland Research Institute. Bodø, Norway, 1-26.

Henry, C.; Hill, F. M.; Leitch, C. M. 2004. The effectiveness of training for new business creation: a longitudinal study, International Small Business Journal 22(3): 249-271.

Jones, P.; Comfort, D.; Eastwood, I.; Hillier, D. 2004. Creative industries: economic contributions, management challenges and support initiatives, Management Research News 27(11/12): 134-145. doi:10.1108/01409170410784644

Leadbeater, C.; Oakley, K. 1999. The Independents: Britain's New Cultural Entrepreneur. London: Demos. 76 p.

Levie, J.; Coduras, A.; Kelley, D.; Saemundsson, R. J.; Schott, T. 2009a. The effect of training in starting a business on subsequent entrepreneurial awareness, attitudes, intention and activity: a 37 nation study, in Conference Paper, International Entrepreneurship Conference. July 2009. Niemegen, The Netherlands, 1-25.

Levie, J.; Hart, M.; Anyadike-Danes, M. 2009b. The effect of business or enterprise training on opportunity recognition and entrepreneurial skills of graduates and non-graduates in the UK, Frontiers of Entrepreneurship Research 29(23): 1-11.

Nilsson, P.; Etelä, N. 2006. Norden - a Creative Powerhouse. Nordic Innovation Centre [online], [cited 05 November 2010].
Available from Internet: <http://www.nordicinnovation. net/_img/ci_syntese.pdf $>$.

Peterman, N. E.; Kennedy, J. 2003. Enterprise education: influencing students' perceptions of entrepreneurship, Entrepreneurship Theory and Practice 28(2): 129-144. doi:10.1046/j.1540-6520.2003.00035.x

Pittaway, L.; Cope, J. 2007. Entrepreneurship education: a systematic review of the evidence, International Small Business Journal 25(5): 479-510. doi:10.1177/0266242607080656

Potts, J.; Cunningham, S.; Hartley, J.; Ormerod, P. 2008. Social network markets: a new definition of the creative industries, Journal of Cultural Economy 32: 167-185. doi:10.1007/s10824-008-9066-y

Power, D.; Nielsen, T. 2010. Priority Sector Report: Creative and Cultural Industries. European Cluster Observatory, March 2010, deliverable D9-1.

Rae, D. 2004. Entrepreneurial learning: a practical model from the creative industries, Education and Training 46(8/9): 492-500. doi:10.1108/00400910410569614

Volery, T.; Mueller, S. 2006. A conceptual framework for testing the effectiveness of entrepreneurship education programs towards entrepreneurial intention, in Conference Presentation, Rencontres St. Gall. St. Gallen, Switzerland, 1-16.

Wilson, N. 2009. Learning to manage creativity: an occupational hazard for the UK's creative industries, Creative Industries Journal 2(2): 179-190. doi:/10.1386/cij.2.2.179/1

Merle KÜTTIM. Researcher. Tallinn School of Economics and Business Administration, Tallinn University of Technology.

Katrin ARVOLA. Researcher. Tallinn School of Economics and Business Administration, Tallinn University of Technology.

Urve VENESAAR. Professor. Tallinn School of Economics and Business Administration, Tallinn University of Technology. 